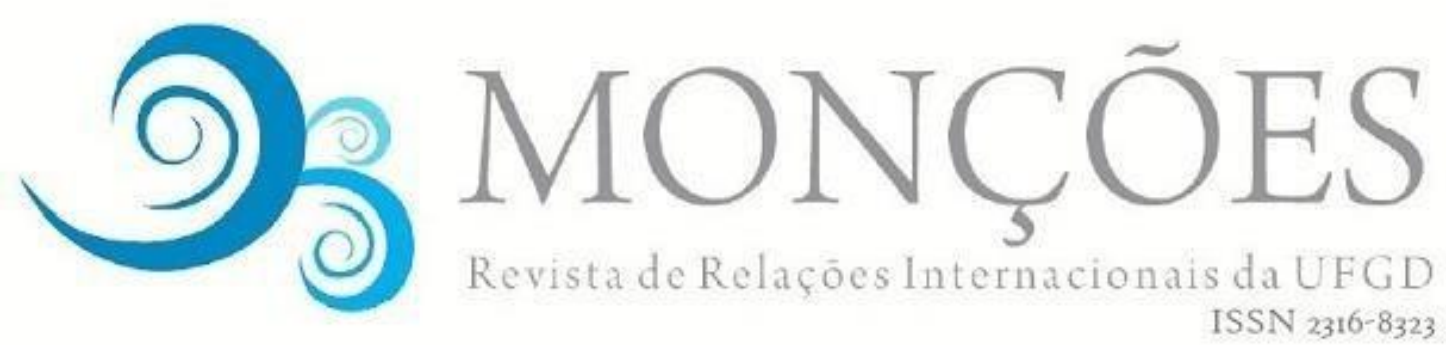

\title{
O PARAGUAI NA AGENDA DA POLÍTICA EXTERNA DO GOVERNO LULA: A RENEGOCIAÇÃO DO TRATADO DE ITAIPU NO GOVERNO LUGO
}

\author{
SARA BASILIO TOLEDO \\ Socióloga, mestre e doutoranda em Relações Internacionais pelo PPGRI San Tiago \\ Dantas (UNESP-UNICAMP-PUC-SP). Pesquisadora NEAI-UNESP.
}

\begin{abstract}
RESUMO: Este artigo visa a apontar, analisar e explicar os elementos determinantes para os avanços da renegociação que modificou o anexo $\mathrm{C}$ das bases financeiras do Tratado de Itaipu, em 2009. A chegada de Fernando Lugo à presidência da república paraguaia em 2008, fez-se a partir de uma ampla plataforma de campanha que colocava a questão da renegociação do Tratado de Itaipu como elemento central. Ao mesmo tempo, o apoio de Lula a Lugo fora fundamental para a viabilização das bases negociadoras. Desta maneira, buscou-se, através de uma análise histórico-sociológica, compreender o papel histórico de ltaipu no redimensionamento das relações entre os dois países, assim como apreender a ascensão de Fernando Lugo no contexto das lutas políticas paraguaias, entendendo o significado e a importância de Itaipu na agenda política do ex-bispo. Por fim, buscou-se apreender os determinantes da política externa brasileira durante os governos Lula e as motivações que viabilizaram a renegociação, assim como apreender o papel de Itaipu na agenda de política externa brasileira. Buscou-se responder a tais questões por meio de extensa revisão bibliográfica e no que toca o processo negociador, além da bibliografia, utilizamos documentos oficiais e, sobretudo, entrevistas realizadas pela autora, com atores fundamentais neste processo, integrantes das Comissões de negociação.
\end{abstract}

Palavras-chave: Itaipu. Política Externa. Brasil. Paraguai.

\section{PARAGUAY ON THE FOREIGN POLICY AGENDA OF THE LULA GOVERNMENT: THE RENEGOTIATION OF THE ITAIPU TREATY IN THE LUGO GOVERNMENT}

\begin{abstract}
This article aims to identify, analyze and explain the determinants of the progress of the renegotiation that modified Annex C of the financial bases of the Itaipu Treaty in 2009. The arrival of Fernando Lugo to the presidency of the Paraguayan Republic in 2008, Was based on a broad campaign platform that raised the issue of the renegotiation of the Itaipu Treaty as a central element. At the same time, the support of Lula to Lugo was fundamental for the viabilization of the negotiating bases. In this way, a historical-sociological analysis was sought to understand the historical role of Itaipu in resizing relations between the two countries, as well as to understand the rise of Fernando Lugo in the context of the Paraguayan political struggles, understanding the meaning and the Importance of Itaipu in the political agenda of the former bishop. Finally, we sought to understand the determinants of Brazilian foreign policy during the Lula administrations and the motivations that enabled the renegotiation, as well as apprehend Itaipu's role in the Brazilian foreign policy agenda. We sought to answer such questions through an extensive bibliographical review and in the negotiation process, besides the bibliography, we used official documents and, above all, interviews conducted by the author, with key actors in this process, members of the Negotiation Committees.
\end{abstract}

Keywords: Itaipu. Foreign policy. Brazil. Paraguay. 


\section{Introdução}

Em julho 2009, os presidentes Lula e Lugo assinavam o documento denominado "Uma nova etapa nas relações bilaterais", em que "os Presidentes destacaram os novos tempos vividos em ambos os países, que facilitam uma convergência de visões e compromissos entre os dois governos.", chamando a atenção para a " necessidade de dinamizar as relações bilaterais, com o propósito de fortalecer os tradicionais laços de amizade e de cooperação, que permitam superar gradualmente as assimetrias entre os dois países". O documento incluía a questão de Itaipu e ia muito além. As relações bilaterais construídas durante os governos Lula-Lugo não tiveram como único destaque a renegociação, mas também abrangeu outras esferas econômicas. Ocorre que, em termos de projeção e importância, a renegociação, sem dúvida, alcançou patamar superior. Os Ministérios responsáveis por viabilizarem o acordo foram o MRE e o Ministério de Minas e Energia, com exceção de um ponto somente, que deveria passar pelo Congresso Nacional brasileiro: o ajuste brasileiro às taxas relativas às bases financeiras do Tratado de Itaipu, inseridos no Anexo $\mathrm{C}$, aprovados pelo senado em 2011 e através do qual o Brasil comprometia-se a apagar o triplo pelos custos de sessão de energia comprados do lado paraguaio, motivo de polêmicos embates políticos dentro e fora do Congresso, que se acentuaram com o processo de polarização política assistidos durante o período em voga e deram combustível para as acusações de partidarização da política externa pela oposição ao governo petista.

Em 2008 o ex-bispo paraguaio, Fernando Lugo, ascendia à presidência da República rompendo com um período de mais de sessenta anos de poder do Partido Colorado. As prospectivas que sinalizavam novos horizontes na vida social e política do país guarani, cristalizavam-se na esperança de inserção social de parcelas marginalizadas pelo apoio da esmagadora maioria dos movimentos sociais. Contudo, a aliança composta para a eleição de Lugo pela reunião de uma miríade de partidos políticos distintos, entre eles o PLRA, que Ihe garantiu maior sustentação eleitoral, fragilizaria a permanência dele no poder, que em 2012 é impedido de exercer suas funções como presidente. Se por um lado, as circunstâncias histórico-sociais viabilizaram a ascensão do ex- 
bispo, por outro a particularidade da história político-social paraguaia deu fôlego à emergência de atores capazes de apontar para mudanças e romper com décadas do monopólio político Colorado.

Acompanhando um amplo discurso difundido por governos progressistas da região, dentre eles o do presidente Lula, no Brasil, Lugo chegava ao poder com um discurso de defesa das parcelas marginalizadas e de amplos benefícios sociais. As afinidades ideológicas entre Lula e Lugo pareciam bastante próximas. Neste novo contexto, as negociações sobre Itaipu sinalizavam-se como mais viáveis. As conversas informais entre Lula e Lugo seguiram-se antes mesmo deste conquistar a vitória nas eleições e ganhariam corpo no decorrer de ambos os governos. $\mathrm{O}$ apoio do presidente brasileiro fez-se fundamental para a vitória do ex-bispo e também para sustentar sua vitória em um Congresso cada vez mais hostil a ele.

Itaipu aparece na história das relações entre os dois países como um elo determinante, cordão umbilical que os uniriam por séculos. Ainda assim, a própria natureza geográfica e econômica em que se inserem os dois países configurar-se-ia como a espinha dorsal dessa relação. Com um território, população e economia extremamente menor que o brasileiro, o país guarani estabeleceu como constante em suas relações com o gigantesco vizinho, o poder de barganha na política exterior. Situado entre os dois gigantes sulamericanos, Argentina e Brasil, o Paraguai procurou tirar vantagens, historicamente, da rivalidade que marcou as relações bilaterais entre estes dois países. Contudo, com Itaipu, o Brasil acabou por trazer o Paraguai para órbita de influência brasileira, no contexto das amplas disputas com o principal rival, Argentina, na Bacia do Prata. Aproveitando-se da dependência energética do pais vizinho, o Paraguai buscou tirar vantagens de tal situação. Esta lógica de barganha, que passa pelo fio condutor de Itaipu, constitui-se uma constante na política externa paraguaia desde então. Soma-se ao relacionamento bilateral, o processo de integração regional inaugurado no fim dos anos 1980 e a chegada de Lula, com uma ênfase declarada nas relações com a América do Sul, estreitamento entre os dois países fora claramente se intensificando. 
A política externa brasileira na era Lula (2003-2010) intensificou o paradigma da cordialidade oficial ${ }^{1}$, consagrando um padrão de relacionamento com os países vizinhos demarcados pela solidariedade, sinalizado por meio dos resultados de contenciosos com a Bolívia (2006), as negociações com a Argentina, na esfera comercial (2005), e, finalmente, com a renegociação do Tratado de Itaipu, em 2009. Pode-se também salientar o ideario de paciência estratégica ou de hegemonia consensual (BURGES, 2008), em que o Brasil buscou construir a liderança regional através da procura de consensos entre os países vizinhos. Tal postura brasileira funcionou como combustão às disputas políticas no cenário doméstico, acentuando, por um lado, a polarização política e, por outro, intensificando a politização ${ }^{2}$ da política externa. Ambos os movimentos atuaram de maneira reverberante, à medida que a politização da política externa aprofundava os embates políticos internos, cuja especificidade de um governo considerado pela oposição como de esquerda, alimentou a polarização política, sinalizada pela disputa PT versus PSDB e suas coligações.

É, pois, considerando tais fatores, que o presente trabalho buscou compreender de que maneira se construíram as relações entre Brasile Paraguai durante os governos Lula-Lugo, na tentativa de apreender os determinantes dessa relação e suas especificidades, tendo como foco a renegociação do Tratado de Itaipu. Dada as circunstâncias sociopolíticas de cada país, questionamos até que ponto houve mudanças nas relações bilaterais ou apenas deu-se continuidade ao padrão de relacionamento tradicional, colocando em

\footnotetext{
1 O Paradigma da Cordialidade Oficial foi um termo cunhado por Cervo (1998) para descrever um comportamento de continuidade na política externa brasileira com o entorno regional. Este paradigma, de maneira geral, expressa-se pelo bom relacionamento com os vizinhos, visando assegurar os interesses brasileiros na região, cujo histórico dos países se distinguem significativamente do Brasil, a começar pela geografia, língua e pelo regime político pós-independência. Tradicionalmente, a chancelaria brasileira adotaria uma política que visa a atenuar conflitos, atuando de maneira cordial com os vizinhos.

2 O termo, à primeira vista, parece redundante, haja vista que, como toda política, a externa também constitui-se como "política". No entanto, nos últimos anos, particularmente após a redemocratizaçã o brasileira, constatou-se um processo de "politização da política externa", no sentido de que esta esfera da política começou a ganhar gradualmente espaço na opinião pública, ao mesmo tempo em que se constatou um "desencapsulamento" do Itamaraty, na medida em que este demonstrou-se cada vez menos insulado, contrastando com o período anterior, em que a política externa alocava-se muito mais dissociada da sociedade, de maneira geral. Ao processo de ampliação do diálogo do Itamaraty com outros atores governamentais, as sim como o maior peso da política externa entre a opinião pública, é que alguns autores cunharam o termo (PINHEIRO e MILANI, 2012; LIMA, 2013). Este processo de politização da política externa elevaria a política externa à esfera de política pública. Ao longo do trabalho, desenvolveremos melhor esta ideia.
} 
questão o caráter conjuntural ou estrutural da postura brasileira diante do acordo em questão.

A metodologia empregada abrange a análise qualitativa, através de análises de discursos, entrevistas e documentos oficiais, além de extensa revisão bibliográfica. Adicionalmente, buscou-se analisar o objeto a partir do referencial teórico do jogo de dois níveis, de Putnan (2005), na medida em que consideramos as preferências políticos domésticas, as coalizões e estratégias negociadoras como fundamentais na confecção do projeto de política internacional de ambos os países em questão.

\section{Itaipu no contexto geopolítico da Bacia do Prata: o redimensionamento das relações brasileiro-paraguaias.}

Pode-se afirmar que o processo de aproximação entre o Brasile o Paraguai inaugurou um marco fundamental com a construção de Itaipu, potencializando a interdependência e favorecendo um quadro de maior intercâmbio entre os países. A construção da "gigante de pedra" viria não somente a inserir definitivamente o Paraguai na órbita de influência brasileira, atenuando a influência que a Argentina exercia sobre o país guaraní e alocando-o sob a lógica dos interesses brasileiros (DORATIOTTO, 2014). A rivalidade que marcara toda a história das relações internacionais do Brasil e da Argentina mediante as diversas disputas em torno do desenho geopolítico na Bacia do Prata característico do século XIX foi sendo resolvida gradualmente a partir dos Acordos que antecederam o Tratado de Itaipu. (BETIOL, 2008; YAHN FILHO, 2005). Neste sentido, é que ao analisar as relações de aproximação entre Brasil e Paraguai deve-se ter como pressuposto a rivalidade e as disputas geopolíticas na Bacia do Prata que tinha como fio condutor, o Brasil e a Argentina (DORATIOTTO, 2014; ITUASSÚ, 1997; BETIOL, 2008).

O Tratado de Itaipu se constitui como o primeiro tratado internacional de integração energética na América do Sul. Firmado em 1973, entre os governos militares brasileiro e paraguaio, desperta até hoje muitos questionamentos e problematizações em diversas esferas, seja pelos governos, partidos políticos, mídia e diversos setores acadêmicos. Da Engenharia ao Direito, da História às 
Relações Internacionais, o tratado é alvo de críticas e elogios. Desde a data das negociações para a assinatura do acordo, já ressoavam, no Paraguai, diversas vozes bastante hesitantes quanto ao real benefício dele, mostrando-se, ao mesmo tempo, temerosas sobre a ameaça "imperialista" brasileira, tal como amplamente compreendido e advogado pelos mais distintos setores sociais e políticos no país guaraní.

O Tratado configura-se, até a atualidade, como objeto de muitas análises e interpretações. Há, pelo lado brasileiro, defensores da ideia de que ele demonstrou extrema habilidade do Brasil em lidar com a questão da integração política e de desenvolvimento econômico, por meio de um arranjo jurídico original, o qual beneficiou ambos os países pelo fato de o tratado viabilizar 0 desenvolvimento econômico de ambas as partes.

O Paraguai, com suas características geográficas, cercado pelos dois vizinhos gigantes, necessariamente, teve sua história atrelada aos interesses desses dois países e historicamente, buscou utilizar-se de tais interesses para alcançar alguns objetivos do ponto de vista da política doméstica. Um momento em que essa lógica ficou muito clara ocorreu durante o regime de Stroessner e sua política pendular (ROLON, 2010). Para Oliveiros Ferreira (2013) o Paraguai sabe que "quando nada se tem, tudo se pode e nada se perde (...) país algum, por maior que seja, pode dar-se ao luxo de querer ditar regras àqueles com quem tem fronteiras e de cujo mercado depende, ainda que pouco". Do ponto de vista geopolítico, o país guaraní pode ser visto como o "Heartland" 3 ou "Estado Tampão".

Entre os analistas, não há consenso entre os ganhos do empreendimento realizado entre o Brasil e o Paraguai com a construção de Itaipu. Seja no próprio Brasil ou no Paraguai, especialistas se dividem quanto a forma de avaliar as relações entre os dois países, passando via de regra, por Itaipu. .Independente de quaisquer interpretações acerca da postura brasileira em relação ao Paraguai, o fato é que estas divergências tem alimentado embates políticos e

\footnotetext{
${ }^{3}$ Conceito geopolítico desenvolvido pelo geógrafo estadunidense Halford Mackinder . O Heartland é um espaço estratégico a partir do qual o controle configura-se necessário para a expansão de um ou mais Estados.
} 
comprometem as relações bilaterais, como ficou demonstrado com a campanha de Lugo à presidência.

De modo geral, as relações entre os dois países após a redemocratização fora marcada por aproximações, marcada fundamentalmente pela mudança de regimes de ambos os países, com os processos de redemocratizações. Tal aproximação possui como fio condutor alguns elementos, são eles: (i) o comércio: o fluxo comercial ultrapassou os U\$ 4 bilhões, o que vale dizer que houve um aumento de cerca de 592\% de 1989 a 2012 (MDIC, 2014), com uma balança comercial superavitária para o Brasil desde 1990 (BRASIL,2014a). Dentre os principais produtos exportados pelo Brasil estão o óleo diesel, fumo e a grande maioria de industrializados para servir o agronegócio, como adubos e fertilizantes. Do lado paraguaio, estão a soja, a carne o milho e o arroz e seus derivados (BRASIL,2014a). (ii) A existência de significativos fluxos migratórios, com os chamados brasiguaios representando na atualidade mais de 400 mil, e, mais de 30 mil paraguaios vivendo no Brasil . (iii) O combate ao tráfico de drogas e a lavagem de dinheiro (FIGUEIRA, 2010); (iv) o Paraguai é um dos maiores receptores de projetos de cooperação do Brasil (IPEA,2010).(v) a interdependência energética, com Itaipu, a qual abastece o Brasil com cerca de 17\% de toda a hidroeletricidade e o Paraguai com 75\% (TAIPU, 2014).

Todos estes elementos adensaram as relações bilaterais, criando uma relação incontestável de interdependência: o Brasil na atualidade é o segundo maior investidor do Paraguai, com uma participação de 19\% a 30\% do PIB paraguaio. No entanto, o Paraguai é um dos países mais pobres da América do Sul, na frente apenas do Suriname e da Guiana. Na atualidade, o país conta com um PIB um pouco superior a U\$S 60 milhões, considerando que nos últimos anos o crescimento econômico alcançou aumentos sem precedentes, com um aumento de cerca de 14\% em 2013 (CARMO, 2013), graças ao aumento da agroexportação, sobretudo de soja (CADEP, 2010).

Inserida numa atmosfera de diversos embates entre chancelarias, governos e opinião pública, Itaipu constitui-se até a atualidade como símbolo de discussões. O fato é que a decisão acerca de sua construção e de seu caráter jurídico, binacional, inaugurou uma nova fase nas relações bilaterais entre os 
dois países, diante da qual os governos posteriores de ambos os países teriam, necessariamente, que lidar.

A história do Paraguai possui intima ligação com seus dois grandes vizinhos, Brasil e Argentina, "principais pólos do subsistema de relações internacionais na região do Prata" (DORATIOTTO, 2002, p.23). As disputas geopolíticas que envolvem a região acabaram por formatar as relações entre o Paraguai e estes dois países, que alcançam um ponto de extrema tensão a partir de 1860, com a atuação mais ativa de Solano López nos acontecimentos platinos, entrando em choque com seus principais vizinhos.

O fim catastrófico da Guerra do Paraguai, gerou marcas profundas ao país guaraní, que se viu obrigado a ceder cerca de 60 mil km de seu território ao Brasil com a assinatura do Tratado de Paz, em 1872, fragilizando ainda mais a posição do país, entre o Brasil e a Argentina. A rivalidade destes dois países era vista por Spkyman, em plena guerra mundial, como um dos grandes focos de conflitos sul-amerciano, exatamente na Bacia do Prata:

\begin{abstract}
Mais importante entretanto para o futuro da America do Sul e a luta de poder entabulada na outra zona de conflito do continente meridional: a bacia do rio da Prata. Aqui os protagonistas sao os dois Estados mais poderosos da America Latina e a recompensa seria a caudilhagem e 0 império do continente sul. De um lado está a Argentina, quase toda em zona temperada, com as mais ricas terras agrícolas do continente e uma população branca, enérgica, dinâmica e com sonhos imperiais; do outro lado esta o Brasil, o maior Estado da América Latina, com uma população superior em mais de três vezes a do vizinho sul, mais rica também em recursos minerais. Esta rivalidade tem para a constelação politica do continente sul a mesma importancia e sentido que a rivalidade Franco-Alemanha na Europa Ocidental ou a antiga rivalidade Áustria-Russa na Europa Oriental. " (apud ITAUSSU, p. 337).
\end{abstract}

A análise de Leonel Itaussu é bastante original e de deveras importância para a análise das relações bilaterais Brasil-Paraguai, na medida em que contextualiza os conflitos na Bacia do Prata a partir de uma ótica geopolítica dos militares. Para tanto, resgata a importância desta Bacia, do ponto de vista estratégico, segundo a visão de uma vertente do pensamento geopolítico brasileiro dos anos 30 (particularmente de Mario Travassos), demonstrando como esta vertente influenciou a política na Bacia do Prata após 1964, visando estabelecer a hegemonia brasileira na região. A visão estratégica brasileira parece ter oferecido resultados satisfatórios, na medida em que altera o equilibrio 
regional nos anos 70, com o deslocamento dos pequenos países platinos Bolívia, Paraguai e Uruguai - para a esfera de influência do Brasil. Para o General Golbery O Brasil deveria efetuar uma aliança com os EUA, no interior de uma estratégia de contenção e, por meio da qual, poderia reivindicar para si uma posição de "barganha leal", devido às características geoeconômicas do país, ocupando, assim, a posição de aliado preferencial dos EUA, como forma de assegurar a defesa no Atlântico Sul e no continente. Das características geoeconômicas brasileiras, distintas e superiores frente aos vizinhos, o militar brasileiro deduzia e defendia a ideia de um Destino Manifesto brasileiro.

Assim, duas visões se destacam na historiografia brasileira ao analisar a importância e o dimensionamento de Itaipu nas relações com o Brasil. A primeira já destacada acima, eminentemente geopolítica, e uma segunda, de vertente liberal semelhante ao conceito de interdependência complexa, tal como fundamentado nos conceitos de Keohane e Nyez em "Poder e Interdependência" (1977), em que o Brasil teria optado pelo condomínio com o Paraguai em torno da energia, como uma forma de garantir os interesses de expansão da crescente indústria brasileira, de modo que esta questão passa a ser preponderante sobre a análise geopolítica. Desta forma, os interesses de cada país acabariam por gerar uma situação de cooperação mútua, ao invés de conflitos. Este processo de cooperação poderia ser observado a partir da sequência de tratados e conversações estabelecidas entre os países da Bacia do Prata. (BETIOL, 2008; YAHN FILHO, 2005). Ainda assim, a situação de confronto característica até os anos 1970 passa a ser revertida para uma relação de cooperação, que alcança o ápice com a assinatura do Tratado de Itaipu. (YAHN FILHO, 2005; BETIOL, 2008).

De maneira geral, a compreensão dos elementos determinantes ou influenciadores na construção de ltaipu envolve variáveis internas e externas que podem ser resumidas, respectivamente, nos seguintes pontos: política econômica desenvolvimentista; projeto geopolítico de hegemonia regional; rivalidade com a Argentina em face das disputas de expansão na Bacia do Prata e, portanto, tentativa brasileira de isolamento do país portenho. Deste modo, é possível afirmar que considerar unilateralmente um único aspecto como subsídio analítico para a justificativa da construção de Itaipu pode ser perigoso, pois, a 
hidrelétrica abrange uma miríade de interesses do Estado brasileiro, colocados diante de circunstâncias internacionais e regionais específicas.

Para Tomáz Espósito (2012a), embora com muitas discórdias de ambos os lados, Itaipu atendia aos interesses da diplomacia brasileira de três maneiras: 1 - a resolução da questão fronteiriça; 2- o interesse de aproximar-se do Paraguai, em detrimento do afastamento da Argentina, de modo a criar um "desenvolvimento associado" entre os países; 3- a promoção do desenvolvimento econômico brasileiro (ESPÓSITO, 2012b). Segundo este mesmo autor, do ponto de vista paraguaio, Itaipu respondia ao interesse de crescimento econômico durante sua construção e, ao mesmo tempo, ao fôlego dado à região fronteiriça, a partir de um novo polo econômico; ao rendimento obtido com a venda da energia ao Brasil e à diminuição da dependência argentina, a partir do estabelecimento de compromissos duradouros com o Brasil. De fato, Itaipu veio a atender aos interesses geopolíticos, econômicos e diplomáticos brasileiros (PECEQUILLO e HAGE, 2007).

\section{Itaipu na plataforma política e na agenda de política externa de Fernando Lugo}

A chegada de Fernando Lugo ao poder presidencial paraguaio apontou para a inédita perda do monopólio do Partido Colorado, que de 1947 a 2008 manteve se intacto em todas as dimensões político-institucionais paraguaias. Neste período, nem mesmo o Partido Liberal, principal opositor do Partido Colorado conseguiu configurar-se como contraponto. Nestas circunstâncias, compreender a ascensão de Fernando Lugo passa por uma profunda analise históricosociológica que leve em conta o processo de fragilização do Partido Colorado e insira o exame das lutas sociais que antecederam a chegada do ex-bispo. Neste sentido, a questão sobre até que ponto a transição democrática alterou a dinâmica socioeconômica e política do país vizinho também se destaca. Isso porque o quadro político do Paraguai com a destituição do presidente Fernando Lugo, em 2012, demonstrou o caráter frágil, debilitário e incompleto da democracia paraguaia. Acusado pelo Brasil e pelos países componentes do Mercosul de antidemocrática, a destituição de Lugo resultou na suspensão do 
Paraguai do Mercosul, exigindo-se, pois, novas eleições como critério de volta do país guarani ao bloco, o que ocorreu em 2013. Muito embora a mudança no regime político tenha ocorrido com a transição, deflagrada pela emergência de instituições democráticas, a consolidação da democracia apresenta-se frágil e instável, representando preponderantemente os interesses de uma tradicional elite econômica, detentora dos poderes políticos. O que leva Britez e Caballero (2010), a ressaltarem os limites de uma democracia sustentada na isenção da alternância de poder, condição necessária para "falar de democracia com propriedade".

Assim, a análise da trajetória que viabilizou a ascensão de Lugo e as circunstancias que demarcaram sua emergência tangenciam a questão do déficit democrático paraguaio e, neste sentido, chama atenção para a problemática acerca da consolidação da democracia no Paraguai, a qual, sem dúvida, configura-se demasiada complexa quando se analisa o histórico político pósStroessner e o período que ficou conhecido como "transição democrática", datada a partir de 1989. Para muitos analistas (GOIRIS, 2000; ROETT e SACKS, 1991; GARBARINO, 2013; LAMBERT e NICKSON,1997), tal problemática é posta nos seguintes termos: embora a mudança no regime político tenha ocorrido, mesmo com a emergência de instituições democráticas, a consolidação da democracia ainda apresentar-se-ia como frágil e instável, devido a problemas de ordem socioeconômica e de uma tradição política patrimonialista, a qual assenta-se em práticas de loteamento partidário das estruturas democráticas (RIVAROLA, 2007).

A eleição de Lugo à presidência da República marcou não somente uma nova fase da política externa paraguaia, mas um novo período da política doméstica, ainda que com muitos resquícios e obstáculos decorrentes do acumulado histórico patrimonialista do Estado guarani. A particularidade de Fernando Lugo, para Lambert (2011a), deve-se a três motivos essenciais: (i) exbispo presidente; (ii) rompeu com 61 anos de poder do Partido Colorado; (iii) pela primeira vez ocorreu uma transição pacífica de governo para outro partido.

A chave da campanha eleitoral de Lugo fundamentava-se em uma base de amplas reformas vinculadas a necessidade de justiça social e distribuição de 
renda, combatendo a pobreza e as desigualdades. Vinculou-se tais reformas a uma questão externa: a renegociação do Tratado de Itaipu, o que geraria recursos relevantes para o investimento em capital social. Somou-se a este argumento a ideia de resgate da soberania nacional e controle dos recursos naturais, fundamentais para dar fôlego ao processo de mudança prometido pelo ex-bispo (CANESE, in CODAS, 2008). Deste modo, desde o início de campanha de Lugo a política externa já se fazia comprometida com o sucesso do governo dele (LAMBERT, 2011a; ESPÓSITO NETO, 2011).

É pertinente observar que a questão da insatisfação com os termos do Tratado de ltaipu não se configurou como inédita durante a campanha de Lugo, assim como a gestão da hidrelétrica binacional. Desde antes da assinatura do Tratado, em 1973, diversos embates no interior do Paraguai - assim como no Brasil - já se opunham contra a assinatura (BALMELLI, 2011). O que ocorreu é que o contexto político da assinatura, sob a ditadura de Stroessner, calou toda a possibilidade real de oposição ao acordo. Com a redemocratização, a insatisfação em torno do tratado foi potencializada, alcançando um momento peculiar sob a gestão de Lugo, que inteligentemente soube captar as insatisfações nacionais por meio de uma bandeira comum: Itaipu.

Paralelamente ao esforço pela renegociação, Lugo buscou dar fôlego à profissionalização do Ministério das Relações Exteriores, ainda assim, teve três ministros das Relações Exteriores, o que indica que o diálogo com 0 ministério não foi tão sereno. Logo quando assumiu a presidência, nomeou Alejandro Hamed Franco (2008-2009), em seguida Héctor Lacognata (20092011) e, posteriormente, Jorge Lara Castro (2011-jun 2012). A redefinição de um papel mais objetivo de política externa foi latente durante a gestão de Lugo. Neste sentido, no contexto de dependência e vulnerabilidade paraguaio, Lacognata identificou três princípios que norteariam a política externa (PARAGUAI, 2008): (i) a recuperação e defesa da soberania nacional; (ii) independência de tomada de decisão e (iii) a recuperação de recursos estratégicos.

Assim, o projeto político de Lugo alinhava-se firmemente aos objetivos de política externa, demandando um papel proeminente desta. Novamente, ressalta-se a vinculação do resgate da soberania nacional com a renegociação 
do Tratado de Itaipu. A hidrelétrica é amplamente vista no Paraguai como representação do poder brasileiro.

O trabalho de Lambert (2011a) chama atenção para uma forte dimensão ideológica em torno da necessidade da renegociação. A retórica da soberania nacional desenhada por Lacognata refletia o programa de governo de Lugo e carregava um elemento ideológico que buscava unir diversas demandas em torno de um elemento: Itaipu. Ao mesmo tempo, o autor salienta o diálogo entre tal ideologia e o pragmatismo, na medida em que a renegociação traria mais ganhos para o país, pelos quais se investiria em aportes sociais.

Ainda que relutante no início das discussões acerca da renegociação" 4, no dia 25 de julho de 2009, os presidentes Luiz Inácio Lula da Silva e Fernando Lugo assinaram em Assunção o acordo "Construindo uma Nova Etapa na Relação Bilateral", que traz inovações significativas no que diz respeito ao tratado. O acordo foi visto no Paraguai como uma grande vitória e, em 2010, foi aprovado no Senado paraguaio e, em 2011, pelo Senado brasileiro. Para Lambert (2011a), o acordo revela um número importante de elementos em termos de relações internacionais paraguaias, os quais marcaram a gestão de Lugo, dentre elas: o papel do Executivo brasileiro, cristalizado na figura do então presidente Lula, que seria motivado pelo "seu desejo de ajudar e dar impulso ao apoio político doméstico a Lugo" (LAMBERT, 2011a); o pragmatismo do acordo, mesmo que sob um prisma ideológico de solidariedade, justiça e soberania, já que o Paraguai necessitava de um aumento no fluxo de renda, e o Brasil, por outro, buscava atenuar qualquer foco de conflito, dada a preocupação acerca da instabilidade política e as consequências desta sob a segurança na fronteira leste com o Paraguai.

\footnotetext{
4 A afirmação do presidente Lula comprova a afirmação: "Em Itaipu, temos um tratado e vamos mantêlo. Um tratado não se modifica". Publicada pela agência EFE, em 22 de abril de 2008.
} 


\title{
3.1 Os principais pontos de discórdia do lado paraguaio
}

Jorge Lara Castro ${ }^{5}$, ao prefaciar o livro de Ricardo Canese, afirma que ao em vez de Itaipu viabilizar o progresso da sociedade paraguaia, o que ocorreu foi o impulsionamento de um "modelo econômico típico de uma estrutura colonial" (CANESE, 2011, p. 12). Ex-ministro das Relações Exteriores do governo Lugo e um dos integrantes da Comissão Negociadora, ocorrida em 2009, Castro, acreditava que as reivindicações a favor da soberania paraguaia, frente aos recursos de poder energético, adquiriria dimensão histórica, chamando atenção para a importância do livro de Canese, La recuperación de la soberania hidroelétrica del Paraguay (2011) ${ }^{6}$, neste processo. De fato, o livro de Canese cumpriu papel de fundamental importância, já que

\begin{abstract}
A primeira edição do livro, apresentada por Fernando Lugo no Comitê de Igrejas Para Ajuda de Emergências (CIPAE), foi o principal instrumento para lançar, em primeiro lugar, a campanha de recuperação da soberania hidrelétrica em Dezembro de 2006, também pela coordenação de Fernando Lugo. Esta campanha culminou momentaneamente com uma manifestação e ato em frente à Itaipu Binacional em Abril de 2007. Logo, foi retomada a campanha com maior ímpeto, como um dos seis pontos fundamentais do programa da APC. Foi, sem dúvida, o principal tema de discussão da campanha eleitoral de abril de 2008, que culminou com o triunfo da APC e a eleição de Fernando Lugo (...). Todo o país tomou partido a favor da necessidade de recuperar a soberania hidroelétrica nacional. (CANESE, 2011, p. 23).
\end{abstract}

Assim, a obra de Canese, além de pautar as linhas programáticas do elemento central da campanha de Lugo, isto é, a defesa pela soberania energética, também pautou o próprio acordo de 2009. Revela-se, portanto, de extrema importância destacarmos alguns elementos centrais na obra de Canese, seja no livro supracitado, seja no ensaio publicado em forma de capítulo no livro de Gustavo Codas, "O direito do Paraguai à soberania", de 2008. Em ambos, Canese objetiva subsidiar o debate acerca de uma definição sobre quais são as políticas de Estado, em termos de energia, mais proveitosas ao Paraguai, independentemente dos governos, isto é, busca estabelecer as bases de uma

\footnotetext{
${ }^{5}$ Ministro das Relações Exteriores durante o governo Lugo (2011-jun 2012). Durante a renegociação com o Brasil, em 2009, cumpriu papel importante, pois ocupava o cargo de vice-ministro das Relações Exteriores. O ex-ministro também foi entrevistado pela autora.

${ }^{6}$ La recuperación de la soberania hidroelétrica del Paraguay, teve a sua primeira edição em 2006, sendo ampliada e reeditada em 2011, ou seja, após a vitória de Lugo. Neste sentido, é interessante notar como o autor reconhece os avanços ganhos com a renegociação de 2009.
} 
política energética de Estado. Reconhece, contudo, as dificuldades neste processo, pois, as elites governamentais paraguaias trocaram "de forma perversa a soberania hidrelétrica nacional por concessões e apoios políticos fornecidos pelas elites dominantes de nossos vizinhos mais poderosos" (CODAS, 2008, p. 25).

Por meio de uma análise histórica sintética, o engenheiro demonstra de que maneira a atual sociedade de consumo gradualmente demanda por mais fontes de energia, ao mesmo tempo que as matrizes energéticas da maioria dos países industrializados estariam assentadas em fontes de energia não renováveis e poluentes, sobretudo dependentes do petróleo. Em face de tais limitações, o Paraguai deveria utilizar de maneira estratégica o potencial hidroenergético do país, sobretudo com as nações vizinhas, cumprindo papel preponderante no processo de integração energética regional. Internamente, 0 Paraguai teve interrompido o processo de desenvolvimento e industrialização iniciado com López (1840-1870), submetendo-se aos mandos das "submetrópoles" Buenos Aires e Rio de Janeiro. Ainda na atualidade, o Paraguai estaria submetido aos interesses do que 0 autor considera uma grande metrópole (no sentido de domínio) no Mercosul: o Brasil.

\footnotetext{
Assim como o mundo está governado por um império - que impões seus interesses pela força da pressão econômica ou militar para o resto da humanidade - no Mercosul existe uma clara metrópole dominante, que é o pólo mais industrializado do Brasil. Esse país, por meio do Itamaraty - uma das chancelarias mais consolidadas em todo o mundo - é quem impõem sua vontade na região. Buenos Aires, a segunda metrópole, exerce um rol parecido ao da Europa com os EUA da América. (CODAS, 2008, p. 54).
}

Neste contexto de aumentos por demandas energéticas, o Paraguai seria o único país no Mercosul com excedentes hidrelétricos, produzindo cerca de 52 mil GWh/ano (a maioria de ltaipu) e com uma demanda elétrica em torno de 7 mil GWh/ano, ou seja, somente cera de $1 / 7$ da produção nacional de hidroeletricidade (CODAS, p. 89). A Bolívia, por exemplo, país pobre, porém com maior disponibilidade de gás natural, deveria se aliar ao Paraguai, que também necessita de gás natural da matriz energética boliviana, para tirar vantagens das situações, articulando, inclusive, no interior do Mercosul, a partir de entidades 
como Urubapol ${ }^{7}$, como alternativa para equilibrar os interesses no interior do Mercosul. Canese utiliza o exemplo da vitória boliviana sobre a nacionalização dos hidrocarbonetos, em 2006, como referência à possibilidade do Paraguai também obter sucesso nas renegociações com o Brasil: "devemos festejar como êxito próprio a nacionalização das jazidas de hidrocarbonetos da Bolívia, assim como o aumento de seu preço unitário de exportação para Argentina e Brasil." (CODAS, 2008, p. 87).

Das três principais usinas hidrelétricas paraguaias, Itaipu, Yacyretá e Acaray, as duas primeiras e maiores produtoras de energia seriam entidades binacionais, firmadas durante a ditadura de Stroessner. Este argumento é também bastante fundamental para entender as reivindicações paraguaias, pois é a partir dele que há a defesa da revisão de ambos os tratados. A consequência por ter firmado tratados internacionais, mediante os quais se concedeu a construção das usinas, seriam nefastas, pois: "ambos os tratados nos obrigam a ceder os direitos de compra aos países associados, caso o Paraguai não utilize sua parte." (CODAS, 2008, p. 91). Equivale, portanto, a dizer, que a soberania sobre o potencial hidrelétrico paraguaio seria usurpada pelas causas do Tratado de ltaipu, impostas no Anexo $\mathrm{C}$, que estabelece que o excedente gerado no lado paraguaio deve ser vendido exclusivamente a preço de custo ao Brasil. Por isso, utiliza-se o termo "ceder", em vez de vender, pois não haveria direito de escolha, mas sim obediência ao acordo. Como consequência, o Paraguai é prejudicado, pois enquanto aumentam os preços internacionais de energia, o país continua "cedendo" energia não pelo preço de custo e de mercado, beneficiando, assim, as elites industriais brasileiras.

Para Canese, "o tratado é um texto ambíguo que põe em dúvida as conquistas da Ata de Foz do lguaçu, porém aonde não se pode ler uma expressa renuncia à soberania hidroelétrica paraguaia" (CANESE, 2011, p. 157). Como exemplo, utiliza o artigo mais polêmico, o XIII, já citado, o qual estabelece que a metade da energia não utilizada deveria ser utilizada pelo outro país, para seu próprio consumo. Para o autor, o trecho em que é citado que "a energia será

\footnotetext{
7 O Urubapol é um bloco de integração regional, criado em 1963, formado pelo Paraguai, Uruguai e Bolívia, mas que não avançou. As discussões em torno dele foram retomadas durante os governos de Lugo, Mujica e Morales, respectivamente.
} 
dividida em partes iguais", reafirma a soberania hidrelétrica paraguaia; no entanto,
a parte negativa é que já não se fala do 'direito de preferência para a aquisição', tal como dizia a Ata de Iguaçu, senão do 'direito de aquisição' da energia que não seja utilizada pelo outro país para seu próprio consumo. Ao desaparecer o termo "preferência", que estava na Ata de Iguaçu, o Brasil tem interpretado, a partir de 1973, que o Paraguai está obrigado a lhe entregar toda 'a energia que não seja utilizada...para seu próprio consumo (CANESE, 2011, p. 157)

Este ponto encabeça as críticas pelo lado paraguaio e fez-se constitutivo no acordo de 2009. De modo geral, segundo Canese, o Tratado de ltaipu configurou-se um retrocesso, se comparado com os termos dispostos na Ata de lguaçu, muito embora não tenha chegado a negar a soberania paraguaia. Dito de outro modo, Canese não afirma que o tratado tenha privado o Paraguai do exercício da soberania sobre a energia elétrica de Itaipu; no entanto, compreende que o acordo apresenta pontos ambíguos, uma vez que a leitura, por parte do Brasil, restringiu a soberania guarani. Caberia, portanto, readequar as necessidades paraguaias aos termos do tratado, o que, segundo o autor, foi impossível de ser feito até 2008, já que o ltamaraty se negava veementemente a discutir. Baseada em uma série de críticas aos termos do tratado, a Federação dos Trabalhadores do Setor Energético (Fetrasep), com a coordenação do então bispo Fernando Lugo e de Ricardo Canese, lança, no dia 6 de dezembro de 2006, uma campanha nacional pela soberania hidrelétrica de Itaipu, a qual culminou com uma concentração em frente a sede de ltaipu Binacional, em Assunção. Ou seja, antes mesmo de Lugo lançar-se à presidência, o que ocorreria somente em 25 de dezembro do mesmo ano, o exbispo já estava envolvido com a questão da luta pela soberania energética. Há 18 dias das eleições, Lula encontra-se como Lugo e, segundo Canese, promete sentar-se à mesa de negociação para compreender as reivindicações paraguaias e buscar uma saída para a questão. Canese (2011) descreve a atitude de Lula como um "feito histórico em que o Brasil aceitava sentar-se com - Paraguai na mesa de negociações sobre Itaipu, pela primeira vez e sem condições, 35 anos depois de firmado o tratado" (CANESE, 2011, p. 230, nota 73). Até então, o engenheiro afirma que o ttamaraty e os representantes de Estado do Brasil apenas argumentavam em torno da ideia que rege os tratados 
internacionais, cristalizada no pacta sunt servanda (os tratados devem ser cumpridos), a qual é criticada por Canese pelo fato deste argumento não compreender às mudanças de circunstâncias. Assim. o autor defende o princípio do rebus sic stantibus, pelo qual um tratado pode ser alterado, considerando mudanças circunstanciais quanto à assinatura do acordo. Como já visto, o principal argumento que rege as críticas do lado paraguaio, no tocante à revisão do tratado, é o mesmo que foi firmado durante as ditaduras militares.

Com a vitória de Lugo, Canese foi convocado pelo presidente paraguaio para desenvolver o programa de soberania energética. Desta forma, a partir das críticas ao acordo brasilo-paraguaio, o engenheiro desenvolveu os seis pontos de reivindicação, os quais sintetizam as principais insatisfações quanto ao Tratado de Itaipu:

1- Soberania hidrelétrica. Livre disponibilidade de energia paraguaia para a venda a outros países.

2- Preço justo pela energia

3- Eliminação da parte ilegítima da dívida de Itaipu

4- Cogestão plena em Itaipu

5- Controle e transparência

6- Execução de obras faltantes

Tais pontos foram entregues a Marco Aurélio Garcia, que visitava Assunção, em 1 de agosto de 2008, pouco antes de Lugo assumir a presidência.

\section{O acordo de 2009 e a PEB do governo Lula}

A diplomacia do governo Lula pautou-se pela busca por maior protagonismo internacional, passando primeiramente pela esfera regional, o que definiu o padrão do relacionamento com os países vizinhos. Neste sentido, a necessidade de liderar a região configurou-se como um imperativo e, como consequência, as reações diante da postura de liderança brasileira na esfera regional esboçaram embates polêmicos nos planos políticos doméstico e regional. É importante destacar que tal problemática demonstrou que as polêmicas geradas a partir da dinâmica das relações com os países vizinhos, seja na esfera bilateral ou multilateral, resultaram em embates calorosos entre 
defensores e opositores da política externa da era Lula, intensificando o debate e também polarizando-o.

Ao longo da história, observa-se uma continuidade na postura brasileira, em atender às reivindicações do lado paraguaio, com a intenção de atenuar supostos conflitos, no contexto do que Cervo (2008) denomina de "Cordialidade Oficial". No entanto, é necessário verificar a particularidade do acordo firmado em 2009, levando em consideração os elementos motivadores da renegociação de ambos os lados, questionando-se, por um lado, até que ponto ela convergiu com as políticas externas do Brasil e do Paraguai e se as afinidades políticoideológicas entre os chefes de Estado, Lula e Lugo, foram relevantes para a negociação ou o que levou o Brasil a aceitar a renegociação foi a necessidade de alcançar os interesses da projeção brasileira no Cone Sul, na esteira da política externa do governo Lula, pautada na ideia de solidariedade. Sem dúvida, as afinidades ideológicas de ambos os governos, somadas ao interesse brasileiro de influência na região, foram imperativas para a renegociação.

Em termos da renegociação, buscamos expor o processo negociador abaixo, considerando ambos os lados.

Logo após sua vitória, o presidente Lugo instituiu a criação de um grupo de estudo energético, instalado em 8 de Maio de 2008. Este grupo foi composto por técnicos, através de quatro comissões, comandadas por Ricardo Canese. $O$ objetivo da criação dos grupos era o de analisar junto com o governo brasileiro, a necessidade de revisão do Tratado de ltaipu, seus anexos e notas reversais, assim como a gestão conjunta da entidade Binacional. A partir dos estudos de cada comissão, foi criado um memorando de agenda temática a ser entregue à Marco Aurélio Garcia, em visita a Assunção em 1 de Agosto de 2008, especialmente para receber tal documento, a fim de oficializar as negociações e demarcar, sobretudo, os principais pontos a serem acordados.

Como resultado do memorando, os governos de ambos os países decidiram criar uma Comissão Negociadora designada a discutir os seis pontos reivindicados pelo Paraguai. 


\section{Comissão Paraguai}

\begin{tabular}{|c|c|}
\hline Jorge Lara Castro & Vice-ministro das relações exteriores \\
\hline Samuel González & $\begin{array}{l}\text { Vice-ministro das obras públicas e } \\
\text { comunicações }\end{array}$ \\
\hline Efraín Enríquez Gamón & Conselheiro de Itaipu Binacional \\
\hline Hugo Ruiz Díaz & $\begin{array}{l}\text { Assessor jurídico da Presidência da } \\
\text { República }\end{array}$ \\
\hline Jorge Rolón Luna & $\begin{array}{c}\text { Representante da chancelaria do Conselho } \\
\text { de Itaipu }\end{array}$ \\
\hline Ricardo Canese & Coordenador da Mesa Negociadora \\
\hline Gustavo Codas & $\begin{array}{c}\text { Assessor para temas energéticos da } \\
\text { chancelaria }\end{array}$ \\
\hline
\end{tabular}

Comissão Brasileira

\begin{tabular}{ll}
\hline Marcio Pereira Zimmerman & Ministro Interino de Minas e Energia \\
\hline Enio Cordeiro & $\begin{array}{l}\text { Sub-Secretário Geral da América do Sul } \\
\text { (Itamaraty) }\end{array}$ \\
Luiz Eduardo Melía de Carvalho e Silva & Chefe de Gabinete do Ministro da Fazenda
\end{tabular}

Jorge Miguel Samek

Valter Luiz Cardeal de Souza

João Bonifácio Cabral Junior

Antônio Otelo Cardozo

Renato Soares Sacramento

Marisete Fátima Daldad Pereira

Hailton Madureira de Almeida
Diretor Geral Brasileiro de Itaipu

Diretor de engenharia da Eletrobrás S.A

Diretor jurídico de Itaipu

Diretor técnico executivo de Itaipu

Eletrobrás

Tesouro Nacional Brasileiro

Tesouro Nacional Brasileiro

Fonte: Elaborado pela autora.

O processo de negociação que se iniciou formalmente em 2008, culminou no documento "Construindo uma nova etapa nas relações bilaterais", firmado em 25 de Julho de 2099 em Assunção e, finalmente, com a aprovação pelos Congressos Nacionais de ambos os países: no Paraguai, em Julho de 2009 e, no Brasil, em Maio de 2011. Contudo, o processo negociador ultrapassou as formalidades, contando com alguns encontros informais que, sem dúvida, configuraram-se de extrema relevância para o desenrolar da renegociação. Os encontros formais foram mediados em suas diversas etapas pelas Comissões 
negociadoras, contudo, os chefes de Estado também participaram de algumas reuniões.

Apresentamos abaixo as principais fases neste processo, envolvendo os encontros formais e informais:

2 de Abril de 2008 (encontro informal): Lugo visita Brasília, em reunião com a Executiva Nacional do PT e o presidente Lula, em que o PT oficializa o apoio à candidatura de Lugo. Na ocasião, Marco Aurélio Garcia declara não haver "agenda tabu" com o Paraguai.

1 de Agosto 2008 : Lula envia Marco Aurélio Garcia e o embaixador Enio Cordeiro para receber oficialmente a agenda paraguaia sobre os seis pontos reivindicados.

17 de Setembro de 2008: Os presidentes Lula e Lugo se encontram em Brasilia. Lugo pela manhã, participou de uma reunião junto à FIESP, e, mais tarde, se encontrou com Lula para discutir as relações bilaterais. Embora a Revista Resenha de Política Exterior do Brasil (RPEB, 2008) não descrevesse que a visita tinha como objetivo oficializar o pedido de negociação, Gustavo Codas (CODAS, 2014b) afirma que a intenção do encontro foi exatamente esta.

29 de Setembro de 2008: Na hidrelétrica de Itaipu, ocorre a primeira reunião entre as Comissões Negociadoras. Os temas abordados foram os mesmos seis pontos apresentados à Marco Aurélio Garcia, em 1ํ de Agosto. Segundo Gustavo Codas, os avanços se deram entre os pontos menos polêmicos, a saber, 4, 5 e 6, respectivamente referentes a cogestão plena; transparência e controle público das contas de Itaipu e à execução das obras faltantes dispostas no Tratado. As auditorias foram aceitas por parte das respectivas direções gerais de Itaipu. Os pontos 1, 2 e 3 foram integrados em um só, e, ambas as partes decidiram pela constituição de Subcomissões, destinadas a estudar tais pontos e apresentar resultados dentro um mês. Para Efraín Goméz, a conclusão desta primeira reunião foi exitosa. Além do mais, os respectivos ministérios de cada país negociariam as obras inconclusas, já citadas acima.

27 de Outubro de 2008: As Comissões Negociadoras se reuniram na Central Hidrelétrica de Itaipu e, dentre os diversos temas, Enio Cordeiro trouxe à discussão questões relativas aos três primeiros pontos, a saber: a livre 
disponibilidade, o preço justo e a questão da dívida. A parte brasileira assinalou que, embora as Subcomissões tenham apresentado dados relevantes, "não foram apresentados dados novos que sirvam de base para um aprofundamento do tema", além de não verem "possibilidade de exportar energia a terceiros países, já que Itaipu se constitui da relação estrita entre Brasil e Paraguai" (GAMÓN, 2012, p. 48).

O Paraguai retrucou, afirmando que a venda a terceiros não se restringe necessariamente a outros países, mas dentro do próprio Brasil, mediante novas formas de comercialização direta $^{8}$. Segundo o lado brasileiro, a integração energética só poderia ser feita no âmbito da UNASUL e, além do mais, a Comissão Negociadora não teria legitimidade para renegociar um Tratado, além de que a própria renegociação possivelmente não seria aceita pelo Congresso brasileiro. Em contrapartida, ofereceu uma ajuda de 1 milhão de dólares para diversos projetos em diversas esferas como linhas de crédito, construção de pontes, etc, a qual o Paraguai não rechaçou, porém advertiu que deveria ser discutida em outra esfera, e que nada tinha a ver com Itaipu.

Os argumentos paraguaios, feitos por Efraín Gómez, direcionaram-se no sentido de ressaltar os benefícios sociais necessários para o Paraguai, da anulação ou a redução máxima da dívida, de modo que "os custos financeiros não sacrifiquem a disponibilidade dos recursos existentes", obrigando o Paraguai a dedicar grande parte dos recursos e esforços complementares para favorecer compromissos financeiros que formam a "cadeia de 'círculo vicioso' da pobreza e não para o melhoramento do nível de vida de seu povo, como se estabeleceu na Ata de Foz do Iguaçu e no espírito da própria letra do Tratado" (GAMÓN, 2012, p. 52). Os entraves quanto aos três primeiros pontos continuaram em aberto, e, se estabeleceu que a delegação brasileira apresentasse na próxima reunião suas contrapropostas em relação a estes pontos.

Quanto aos pontos 4, 5 e 6, estabeleceu-se que o Conselho de Administração da entidade encontrariam mecanismos para solucionar a

\footnotetext{
${ }^{8}$ A venda do excedente energético do lado paraguaio ao Brasil, é feita exclusivamente à Eletrobrás. O Paraguai defende que poderia vender a outras empresas de energia, mesmo que só restritamente ao Brasil, já que o Brasil se colocou veementemente contra a venda da energia do lado paraguaio a terceiros países.
} 
efetivação da cogestão administrativa e, uma forma conjunta de estabelecer um relacionamento entre ambas as controladorias "para unificar critérios e realizar auditorias complementares e jurisdicionais que correspondam a cada país" (GAMÓN, 2012, p. 53).

Por fim, o lado brasileiro argumentou, no sentido de que Itaipu representava cerca de $19 \%$ do abastecimento de energia elétrica brasileira, e, que o país também conta com outras formas de energia. $O$ lado paraguaio respondeu com a alegação de que 19\% não se constitui irrisório para um país da dimensão do Brasil e, sobretudo, que o "coração financeiro e turístico do país", São Paulo e Rio de Janeiro, dependiam em mais de 90\% da energia de Itaipu. Segundo Lara Castro (CASTRO, 2014), a questão da segurança energética configurou-se como uma das questões mais proeminentes no processo negociador pelo lado brasileiro. Ainda assim, os pontos 1, 2 e 3 ficariam para a próxima reunião.

19 de Dezembro de 2008: Na Central Hidrelétrica de Itaipu, reuniram-se mais uma vez as Comissões Negociadoras, além do Ministro de Minas e Energia, Edson Lobão, e o diretor geral da Eletrobrás, além de uma equipe técnica de apoio. Contudo, a reunião foi a mais breve, durando cerca de 3 horas (13-16h). A delegação brasileira afirmou que as conversas a nível técnico afetaram, a princípio o tratamento formal dos pontos originais e que, portanto, os pontos 1 , 2 e 3 seriam "elevados a consideração da decisão política dos governos, em seu mais alto nível", (GAMÓN, 2012, p. 58), sendo formalizadas por ambas as chancelarias. A delegação brasileira jogava nas mãos do Presidente a decisão pela renegociação. Daí a diante, as reuniões seriam feitas entre Lula e Lugo diretamente.

30 de Janeiro de 2009: Lula e Lugo se encontram em reunião informal no Fórum Social Mundial em Belém (PA). Este encontro, segundo todos os entrevistados $^{9}$, foi o mais importante para o desenrolar da renegociação. Segundo Gustavo Codas, o presidente Lula identificou um "problema político" que estaria obstruindo o processo de negociação e pede à Dilma Rousseff para

\footnotetext{
${ }^{9}$ Os entrevistados foram Gustavo Codas, Jorge Lara Castro e Ricardo Canese, entre os dias 27 e 30 de Outubro de 2014.
} 
que com uma equipe, separadamente, estabeleça um balanço do que já foi negociado e das possibilidades de avanço. Haja vista que a decisão de colocar nas mãos de Dilma fora informal, não encontramos nenhuma documentação relativa a o que Dilma e sua equipe concluiu, restando-nos somente os relatos dos entrevistados que acompanharam mais proximamente o encontro.

7 de Maio de 2009: Lula e Lugo se encontram em Brasilia e decidem assumir diretamente as negociações, acompanhado das respectivas chancelarias e das Comissões Negociadoras. No entanto, a estas últimas não caberia chegar a nenhuma conclusão, mas apenas identificar divergências e convergências. O canal direto entre os presidentes, portanto, é que determinaria a renegociação.

25 de Julho de 2009: Em Assunção, Lula e Lugo assinam o a Declaração Conjunta "Construindo uma nova etapa na relação bilateral". O documento conta com 31 pontos $^{10}$.

22 de Outubro de 2009: O acordo foi aprovado no Congresso Paraguaio

Maio de 2011: Acordo aprovado no Congresso brasileiro. A votação na Câmara ocorreu no dia 07 de Abril e no Senado, no dia 12 de Maio.

\subsection{Acordo sobre as Bases Financeiras do Anexo C do Tratado de Itaipu}

Diversos foram os compromissos expressos na Declaração Conjunta apontada acima. No entanto, todos, com exceção de um ponto apenas, foi encaminhado ao Congresso. O restante ficou sob a responsabilidade do MRE e dos Ministérios supracitados. O ponto levado ao Congresso brasileiro, por se tratar de uma questão que indiretamente altera os valores predispostos incialmente na base financeira estabelecida no Anexo $C$ do Tratado, foi a alteração em relação ao pagamento que o Brasil faz ao Paraguai, pela cessão de energia não-utilizada pelo Paraguai, que é comprada pelo Brasil, tal como expressa no Tratado:

\footnotetext{
${ }^{10} \mathrm{O}$ documento completo encontra-se no site do MRE. Dis ponível em: < http://daimre.serpro.gov.br/atos-internacionais/bilaterais/2009/b_6393/>.
} 


\begin{abstract}
Artigo XIII
A energia produzida pelo aproveitamento hidrelétrico a que se refere 0 Artigo I será dividida em partes iguais entre os dois países, sendo reconhecido a cada um deles o direito de aquisição, na forma estabelecida no Artigo XIV, da energia que não seja utilizada pelo outro país para seu próprio consumo.
\end{abstract}

Em primeiro lugar, importa destacar que diversas Notas Reversais foram trocadas ao longo de diversos governos, acerca de mudanças quanto aos valores pagos à parte da energia comprada pelo Brasil, que corresponde ao excedente paraguaio, o qual corresponde na atualidade a cerca de $5 \%$ de todo os $50 \%$ que cabe a parte paraguaia. Como destacou o relator do texto para a aprovação no Congresso, deputado Doutor Rosinha (PT-PR), "desde a assinatura do Tratado de ttaipu as Partes firmaram nada menos que 23 acordos por trocas de notas sobre assuntos bastante variados". (BRASIL, 2011).

De fato, várias foram as notas reversais que aumentaram o montante pago ao Paraguai pela compra do excedente, pelo aumento do fator multiplicador por sessão de energia. Foram trocadas três notas reversais, contando com a de 2009, acerca do fator multiplicador: a primeira foi estabelecida em 1985 e contava com uma evolução gradual do fator multiplicador, indo de 3,5 em 1985 até 4,0 em 1992, prazo final do aumento. A segunda nota data do governo Lula, firmada mediante Notas trocadas entre os Ministro das Relações Exteriores dos respectivos países, Celso Amorim e Leila Rachid, em 2005, passando a vigorar em $1^{\circ}$ de Janeiro de 2006. A única nota que passou pelo Congresso brasileiro foi a de 2009, que aprovada, passou a vigorar em Maio de 2011. Portanto, embora por três vezes as notas reversais viabilizaram o aumento do fator multiplicador, constata-se que houve um aumento gradual de 10 diferentes fatores multiplicadores, já que a nota de 1986 previa 7 aumentos consecutivos, de 1985 até 1992. Além disso, a Nota Reversal de 1986 alterava a indexação dos juros da dívida, para 7,5\% ao ano, somados à inflação americana no período. A dívida foi corrigida em 2007 novamente, pela Medida Provisória n. 357: "A correção adicional pela inflação americana foi mantida, mas a maior parcela (63\%) passou a ser reajustada também com juros de $7,5 \%$ ao ano, e o restante 
de 4,5\%" (CARDOSO, 2010, p. 145). ${ }^{11}$. Segundo Paula (2014), desde o governo de Nicanor Duarte Frutos, o Brasil buscava criar estímulos para que o Paraguai utilize sua parte correspondente, pois, "a partir do momento em que o Paraguai utilizar a energia que lhe é de direito não haverá foco em reivindicações sobre o valor a ser pago por sua energia" (PAULA, 2014, p.112). A questão acerca da dívida é ainda bastante debatida. Em 2013, o Paraguai encomendou um estudo especializado à Universidade de Columbia. Segundo o estudo, a dívida paraguaia de Itaipu já deveria ter sido quitada, por conta dos encargos sobre os juros indevidos cobrados ao longo dos anos. O estudo considerou alguns problemas centrais, dentre os quais, as altas taxas de juros, que deveriam ser de $5 \%$ ao ano. O estudo ficou conhecido como "Relatório Sachs". (COLUMBIA, 2013, p.76 apud PAULA, 2014). Ainda assim, há uma grande polêmica em torno da dívida. Em resposta ao estudo, o embaixador Rubens Barbosa, em artigo no jornal O Estado de S. Paulo, no dia 23.07.2013, apontava que o estudo apresentava equívocos e "meias verdades", pois, o valor da venda de energia seria determinado pelos custos de manutenção e produção da usina dividida pela potência instalada, o que significa que até 2023, quando a dívida for totalmente quitada, o valor da energia não deve tomar como parâmetro o valor de mercado. Barbosa alegava que as taxas de juros acordadas no Tratado e as revisões feitas em 1997 e 2007 eram taxas praticadas no mercado da época e que "o relatório Sachs não considerou os benefícios que o Paraguai recebe como royalties, valor pago pela cessão de energia e os "fundos sociais" de Itaipu" (apud PAULA, 2014, p. 106).

\footnotetext{
${ }^{11}$ Itaipu foi financiada a partir de empréstimos internacionais com lastro na taxa de juros dos EUA, que passa de $11,2 \%$ para $21,5 \%$ em 1981. Desta maneira, a dívida de Itaipu aumentou de maneira exorbitante. Incialmente, Itaipu fora calculada em cerca de U\$S 10 bilhões, no entanto, posteriormente, devido aos juros iniciais, este valor subiu para U\$S 17 bilhões. Mais à frente, foram captados mais recursos, os quais, devido à crise dos anos 80 , como já referido, incidiram sobre o aumento galopante da dívida. Estes empréstimos somados chegaram aos U\$S 27 bilhões e foram remunerados a partir de dois referenciais: uma taxa de juros fixa de 7,5\% e um fator de ajuste calculado com base na média ponderada de dois indicadores que medem a inflação estadunidense. As reivindicações paraguaias quanto a dívida de Itaipu, considerada "espúria", vão no sentido de defender que devido a tais empréstimos (os quais foram captados pelos brasileiros), sob altas taxas de juros, a correção do saldo devedor superou os pagamentos efetuados, aumentando injustamente, a dívida. (Entrevista com Gustavo Codas). Segundo Enio Cardoso, o pagamento total já efetuado ultrapassa os U\$S 49 bilhões, embora o saldo devedor ainda seja de U\$S 19 bilhões.
} 


\subsection{Um balanço da renegociação}

O exame do processo negociador nos remete a algumas conclusões importantes: o papel dos executivos de ambos os países como atores preponderantes na tomada de decisão. Uma vez que no Paraguai, homogeneamente defendia-se o acordo, o papel mais importante neste processo, sem dúvida, veio do presidente Lula (CARDOSO, 2010), na medida em que enfrentou a oposição e, contrastando com argumentos das Comissões técnicas, percebeu que o problema para a efetivação do acordo constituía-se, sobretudo, político e que, portanto, a saída a ser dada deveria ser política também. Isto ficou muito claro no encontro que os dois presidentes tiveram no Fórum Social Mundial em 30 de Janeiro de 2009: na ocasião, Lula afirmou se tratar de um problema político, e, depois de separadamente conversar com Lugo, decidiu que Dilma deveria rever a questão a fim de viabilizá-la. Ademais, é pertinente notar que antes mesmo das eleições, Lugo recebe a aprovação da direção do PT quanto a sua candidatura, mesmo sabendo que a principal plataforma de campanha de Lugo era a renegociação.

Percebe-se, desta maneira, que as afinidades ideológicas e as relações Lula-Lugo foram determinantes para a concretização do acordo, pois, a Comissão Negociadora brasileira não aceitou os argumentos paraguaios, rebatendo-os dentro do princípio de respeito aos termos do Tratado, além de questões técnicas específicas. Ao não se chegar a nenhum consenso, decidiuse que a questão seria decidida nas mais altas instâncias do poder Executivo.

As entrevistas realizadas durante a pesquisa, com os atores importantes do lado paraguaio, foram fundamentais para clarificar o processo negociador e a importância do papel do presidente Lula neste processo. Os diversos Ministérios envolvidos parecem ter se adequado à perspectiva do presidente. Isso talvez seja explicado pela própria estrutura do poder Executivo baseada em nomeações, dificultando a oposição dos diversos Ministros diante do presidente da república (FIGUEIRA, 2009). Haja vista as diversas questões do ponto de vista técnico, de inviabilidade do acordo, a negociação aparece como eminentemente política, tal como destaca Sales:

O Ministério de Minas e Energia e os dirigentes brasileiros de Itaipu, em várias ocasiões, opuseram-se a qualquer alteração do Tratado de 
Itaipu. O lado brasileiro de Itaipu, fartamente munido de números, provou o quão descabidas eram as propostas paraguaias. Mas tanto o MME quanto a margem esquerda de Itaipu foram vozes isoladas e, como em ocasiões anteriores, outros ministérios, "tratoraram" a argumentação técnica, sacramentando a suspeita inicial de que os interesses políticos eram mais importantes (apud CARDOSO, 2010, p. 168).

Ainda que 0 acordo se destaque pelas afinidades políticas entre os dois governos, o histórico das relações bilaterais entre Brasil e Paraguai denota que o Brasil sempre buscou atender aos interesses do país vizinho, seguindo uma linha tradicional da chancelaria brasileira de manutenção da cordialidade oficial, como denomina Cervo (1998), e assim, garantir a manutenção de uma convivência positiva com o entorno regional. No entanto, o paradigma da cordialidade oficial elaborado por Cervo (1998) salienta que os ganhos obtidos com as concessões devem ser benéficos para o Brasil; isto é, perde-se para ganhar. Neste sentido, até que ponto o acordo fora benéfico ao Brasil? 0 discurso da chancelaria do governo Lula aponta que no contexto da política externa deste governo, de busca pela liderança regional e intensificação dos laços de integração regional, o acordo fora um sucesso (AMORIM, 2013). A oposição, por sua vez, apontou que o preço a ser pago pelo apoio paraguaio onerava o tesouro nacional, e, portanto, o cidadão brasileiro, numa lógica de perde-se para perder. Mas o Brasil, considerando sua superioridade econômica, não ganhou com o apoio paraguaio? . A resposta para tais questões parece-nos delicada, e, não buscamos aqui respondê-las, mas apenas apontá-las e problematizá-las.

É importante considerarmos a premissa de que estruturalmente o Brasil sempre buscou atender às reivindicações paraguaias visando manter este país em sua órbita de influência. Este elemento, de fato, aparece em todos os discursos dos atores estatais brasileiros favoráveis ao acordo: o Paraguai deveria ser atendido, haja vista as assimetrias. Assim, houve um encontro entre os interesses paraguaios e brasileiros, e, o Paraguai soube tirar proveitos circunstanciais. Portanto, parece-nos que além de acompanhar um traço estrutural da chancelaria brasileira, a renegociação de 2009 apresentou uma particularidade, que é a afinidade política entre os Executivos de ambos os países e a proeminência do presidente Lula nas negociações, cumprindo um 
papel determinante. Além disso, os embates no legislativo demonstraram acentuada polarização, que se desdobra, inclusive, na forma como a oposição vê a inserção internacional e regional brasileira. Diferentemente das alterações do fator multiplicador de 1986 e 2006, o acordo de 2009 via inicialmente Notas Reversais passou pelo Congresso, visando ganhar maior legitimidade e abafar qualquer tipo de oposição. Adicionalmente, o apoio dos Ministérios, divulgando notas com seus respectivos pareceres, demonstrou a adequação dos propósitos do presidente Lula com os demais ministérios, inclusive o ttamaraty.

Quanto à juridicidade do acordo, a questão parece ainda ficar em aberto, e, de fato manifesta-se deveras polêmica. Para a chancelaria brasileira, assim como para Cardoso (2010), o fato de a alteração ter sido feita em um Anexo do Tratado, não altera o Tratado, substancialmente:

\begin{abstract}
Com a assinatura da Declaração Conjunta, o Estado brasileiro conseguiu evitar uma alteração no Tratado de Itaipu. As medidas adotadas implicam a revisão de índices de correção que estão em anexos. Dessa forma, foi mantida uma tradição da diplomacia brasileira, que historicamente, desde os tempos do Barão do Rio Branco afirma o princípio de pacta sunt servanda (os tratados têm de ser respeitados), ou seja, o que foi negociado não se pode mudar unilateralmente.(CARDOSO, 2010, p. 165).
\end{abstract}

No Paraguai, por outro lado, oposição e governo convergiram com a positividade do acordo e, de maneira geral, a renegociação foi vista como um grande sucesso. Dizia-se que pela primeira vez o Brasil aceitou sentar-se na mesa de negociação com o Paraguai sobre ttaipu, de modo que o feito fora considerado histórico ${ }^{12}$. Atribui-se à política externa brasileira de então, fundamentada no aprofundamento dos laços regionais através do aprofundamento da integração regional e, sobretudo, ao próprio presidente Lula e sua aproximação com a esquerda paraguaia, encabeçada por Lugo, a explicação para o sucesso das negociações. De fato, com o acordo, o Paraguai acabou por receber uma quantia equivalente a $2 \%$ de seu PIB: U\$S 240 milhões ao cumprir com uma promessa tão importante de campanha, acabou ganhando respeito de alguns setores duvidosos quanto ao acordo, dentre eles, os próprios

\footnotetext{
12 Gustavo Codas, Jorge Lara Castro e Ricardo Canese manifestaram admiração e satisfação quanto ao acordo e à postura brasileira. Para eles, pela primeira vez o Brasil aceitou sentar na mesa de negociações com o Paraguai sobre Itaipu, graças à política externa do governo Lula e, especialmente, à figura do próprio Lula.
} 
liberais, embora não fora suficiente para sua sustentação no poder (LAMBERT, 2011b). Embora a renegociação tenha sido encarada positivamente, agregando capital político, é pertinente considerar que, se mesmo com o acordo o ex-bispo sofrera um impeachment, é bem possível que caso não tivesse conseguido sucesso nas negociações com o Brasil, o juízo político que sofrera poderia ter ocorrido mais cedo.

Cabe lembrar que o discurso acerca da necessidade da renegociação, por parte de Lugo e dos setores que the apoiavam, sempre fora o de que seria necessário canalizar os recursos decorrentes do acordo, aos setores sociais mais carentes. Ou seja, os recursos seriam capital social. No entanto, não houve garantias por parte do governo brasileiro a respeito do que seria feito com 0 dinheiro. Ademais, nenhum dos entrevistados soube dizer para onde os recursos foram canalizados, sugerindo-nos que procurássemos o Ministério da Fazenda.

\section{Considerações Finais}

É em um quadro complexo de uma democracia fragilizada que ocorre a ascensão de Fernando Lugo, reflexo, das contradições da própria estrutura sociopolítica paraguaia. $O$ formato de alianças políticas, combinando elementos diametralmente opostos, como a dependência do apoio liberal e promessas de amplas reformas sociais, tocando nos interesses dos grandes proprietários, acabou por desestabilizar o governo de Lugo, expondo, assim, as bases arcaicas de uma democracia que se constituiu limitada, de maneira que, gradualmente, o ex-bispo foi perdendo o apoio do Congresso e isolando-se politicamente. Ainda que o acordo com o Brasil, em 2009, tenha conferido maior fôlego à permanência dele, tal fato não se demonstrou suficiente para viabilizar o término do seu mandato, de acordo com Lambert (2011b), demonstrando, por um lado, que as forças políticas tradicionais cristalizadas no Partido Colorado ainda exercem relativo domínio sobre as esferas das classes dirigentes e nas disputas de classe no Paraguai e, por outro, que as relações com o Brasil configuram-se fundamentais para a dinâmica política paraguaia. 
A política externa do governo Lugo acabou por sintetizar as diversas contradições da fragilidade estrutural do Estado paraguaio, ao mesmo tempo em que também foi capaz de utilizar algumas debilidades decorrentes da própria natureza geopolítica do país guarani, como recursos de poder, sobretudo, no cenário regional. O principal fator que ilustra tal reflexão, sem dúvida, projeta-se na renegociação do Tratado de Itaipu, em 2009, na qual, utilizando os interesses do Estado brasileiro no contexto regional e internacional, o ex-bispo soube trabalhar com tais interesses a seu favor.

Itaipu configurou-se, ao longo de toda a sua história, como elemento de dissenso do lado paraguaio. O país soube aproveitar as assimetrias com o Brasil para conquistar ganhos significativos em diversos momentos, alcançando seu ápice com o acordo, em 2009, pelo qual foi triplicado o fator multiplicador pela cessão de energia, alterando, assim, as bases financeiras do Anexo C, do Tratado de Itaipu.

Do lado brasileiro, o acordo gerou polêmicas, cristalizadas, sobretudo, nos embates entre oposição e governo, acentuando as posturas polarizadas em torno das propostas de política externa e deflagrando diversas críticas ao modelo de inserção internacional e regional preconizados pelo governo Lula. Críticas em torno do caráter partidarizado da política externa, sob a influência do PT, e supostos devaneios românticos ao redor de uma liderança regional fundamentada no preceito de solidariedade, lideraram os argumentos da oposição, encabeçada pelo PSDB, nas sessões pela aprovação da renegociação, estabelecidas no Congresso brasileiro, em 2011.

Diversas análises geopolíticas demonstram que Itaipu foi, sobretudo, uma decisão política de trazer o Paraguai definitivamente para a órbita de interesse e influência brasileiras, no contexto da rivalidade da Bacia do Prata, o que remonta a própria formação dos Estados Nacionais na região, conforme acentuou Doratioto, (2014; 2012). A estratégia geopolítica brasileira de assegurar fronteiras e garantir a hegemonia na região encabeçava o desenho geopolítico do projeto dos governos militares, segundo demonstrou Itaussu (1997). Contudo, ao buscar aproximação definitiva com o Paraguai, criava-se uma relação de interdependência mútua e inaugurava-se um trajeto de discussões inacabáveis entre Brasil e Paraguai. 
Observou-se que, historicamente, a chancelaria brasileira seguiu uma linha constante de concessões ao Paraguai, não somente com Itaipu, mas em todos os âmbitos das relações bilaterais. Este traço potencializou-se com o modelo de política externa adotada pelo governo Lula, fundamentado no princípio de solidariedade regional. Soma-se a isso a ascensão de Fernando Lugo e a particularidade de sua campanha, diretamente dependente de promessas relacionadas ao Brasil. Assim, a própria sustentação do ex-bispo dependia das negociações com o país vizinho. A peculiaridade deste contexto convergiu para a viabilidade das negociações, que teve como principal vetor a afinidade ideológica entre os presidentes Lula-Lugo. Portanto, embora a chancelaria brasileira siga uma linha de aproximação, diálogo e, muitas vezes, concessões aos interesses paraguaios, o acordo de 2009 foi potencializado por tal peculiaridade: o casamento entre as linhas gerais da política externa do governo Lula e os interesses do governo Lugo, fortemente relacionados com a dinâmica política doméstica paraguaia e a necessidade de sustentação do exbispo no poder.

A análise do processo de negociação, em relação ao acordo de 2009, demonstrou a proeminência do presidente Lula neste processo e o acomodamento de outros setores do Executivo Nacional aos interesses deste chefe de Estado. A figura de Lula foi determinante para a efetividade do acordo. Ainda assim, diante dos questionamentos acerca da impossibilidade de alteração do Tratado de ltaipu, o discurso oficial foi o de que este não foi alterado, na medida em que apenas mexeu-se em pontos referentes a um anexo. Manteve-se, assim, a prevalência da defesa do princípio pacta sunt servanta, muito embora tal premissa seja questionável mediante a observação de que, na prática, a ideia de alteração de um anexo, constitutivo do corpo de um tratado, altera, necessariamente, o próprio acordo.

Por fim, se do lado brasileiro o acordo foi motivo de diversos questionamentos, do lado paraguaio, foi recebido com grande alarde e encarado como feito histórico, na medida em que, pela primeira vez, um presidente brasileiro aceitou sentar-se na mesa de negociações para discutir diretamente o Tratado de ltaipu. 
Ainda que com o argumento de reverter os recursos obtidos com a negociação em capital social, o lado paraguaio não ofereceu nenhuma garantia neste sentido e, em contrapartida, o governo brasileiro também nada exigiu, o que revela que Itaipu é também um problema referente à política doméstica paraguaia, pois depende da vontade política de efetivar reformas na administração dos recursos de ltaipu, os quais, em sua esmagadora maioria, são repassados para o Tesouro, assim como os ganhos de ltaipu são destinados aos benefícios sociais. Este ponto, sem dúvida, parece-nos imperativo quanto ao real benefício do acordo.

\section{Referências bibliográficas}

AMORIM, Celso. Palestra dada no Memorial da América Latina, no IV Simpósio de Relações Internacionais do PPGRI San Tiago Dantas, em São Paulo, no dia. Disponível em: < www.blogaci.unesp.br/santiagodantas. 2013.

BALMELLI, Carlos Mateo. Itaipú: Una reflexión ético-política sobre el poder. Ed.Aguilar. 2011

BRASIL. MDIC.2014. Ministério do desenvolvimento, indústria e comércio: Disponível em: http://www.desenvolvimento.gov.br/sitio/interna/interna.php?area=5\&menu=2081 Acesso em:: 03.01.2015

BRASIL. Ministério das Relações Exteriores. 2008a. Manual de práticas diplomáticas brasileira de atos internacionais, 2008.2 Disponível em: $<$ http://sistemas.mre.gov.br/kitweb/datafiles/IRBr/pt-

br/file/CAD/LXI\%20CAD/Direito/MANUAL\%20de\%20procedimentos\%20-

\%20atos\%20internacionais.pdf>. Acesso em:: 22.01.2014.

BRASIL. Anais do Senado Federal. Atas das sessões 69 e 70 da $1^{\underline{a}}$ sessão legislativa ordinária da 54aㅡ legislatura. Maio. 2011.

BETIOL, Lércio F. Itaipu: Modelo Avançado de Cooperação Internacional na Bacia do Prata. Rio de Janeiro. Ed. Getúlio Vargas, 1983

O entorno geográfico na diplomacia brasileira dos séculos $X X-$ XXI. Revista Política Externa. Vol.19. 2010

BRITEZ, Edwin e CABALLERO, Javier Numan. El Paraguay Actual. 2ª parte.1998-2010. Ed. El Lector. Assunção. 2010

BURGES, Sean. Consensual Hegemony: theorizing Brazilian foreign policyafter the cold war. International Relations. V.22, n. 65. Pp.65-84. 2008.

CADEP. Setor Rural Paraguayo: una visión general para um diálogo informado. No. 10. 2010 
CARDOSO, Guilherme Rios. A Energia dos Vizinhos: uma análise da política externa do governo Lula na "nacionalização" do gás boliviano e nas alterações do Tratado de ItaipuDissertação de mestrado em Relações Internacionais. PUC-RJ.2010

CARMO, Maria. Paraguai descola do Brasil e tem 3ํmaior crescimento do mundo em 2013. BBC Brasil. Jan. 2014. Disponível em: $<$ http://www.bbc.co.uk/portuguese/noticias/2014/01/140119 paraguai economia pai mc>. Acesso em:: 05.02.2015.

CASTRO, Jorge Lara. Entrevista concedida à autora, em Assunção- Paraguai, em 28.10.2014.

CODAS, Gustavo. O direito do Paraguai à Soberania. 1르 Edição. São Paulo. Ed. Expressão Popular, 2008

El Acuerdo Lugo-Lula del 25 de Julio de 2009 y la nueva realción bilateral Paraguay-Brasil. Curso para diplomatas Sul-Americanos. 4 a 15 de abril de 2011. Rio de Janeiro. Palácio Itamaraty. Disponível em: http://www.funag.gov.br/biblioteca/dmdocuments/IX_Curso.pdf

CERVO, Amado Luiz. Eixos conceituais da política exterior do Brasil, RBPI, ano 41. 1998 São Paulo: Saraiva, 2008.

Inserção Internacional: a formação dos paradigmas brasileiros.

ESPÓSITO NETO, Tomás. Os eixos da política externa do Paraguai: de 1954 a 1989. Boletim Meridiano 47. Vol.13, no.134.

As Possibilidades e os Limites do 'Realismo Periférico': A política externa do Paraguai de 1954-89. Artigo apresentado à ABRI. 2011

As Relações brasileiro-paraguaias na era pós-Lugo: uma análise prospectiva: Conjuntura Austral, v. 3, p. 17-33, 2012b.

Itaipu e as relações brasileiro-paraguaias de 1962 a 1979: fronteira, energia e poder. Tese de doutoramento em ciências sociais. PUC-SP. 2012a.

PAULA, Fernandes. Um balanço das relações brasileiroparaguaias nos governos Lula/Dilma (2003-2012). 2014. Disponível em: <http://www.grupoparaguay.org/P_NetoYDePaula_2014.pdf> . Acesso em:: 11.02.2015.

CANESE, Ricardo. La recuperación de la soberania hidroelétrica del Paraguay. Assunción. 2011.

Fisenge. Entrevista dada ao site. Junho.2008. Disponível em:<ww. http://fisenge.org.br/2008/07/30/entrevista-engenheiro-ricardo-canese-deve-assumirnegociacoes-de-itaipu/>. Último acesso em: 26/09/2014b.

DORATIOTO, Francisco: RELAÇÕES BRASIL-PARAGUAl: Afastamento, tensões e reaproximação. (1889-1954). Fundação Alexandre de Gusmão. Brasília, 2012.

Maldita Guerra: Nova História da Guerra do Paraguai. Companhia das Letras. São Paulo. 2002

O Brasil no Rio da Prata (1822-1994). Ed. FUNAG. 2014

FIGUEIRA, Ariane. Processo decisório em Política Externa no Brasil. Tese de doutorado. Departamento de Ciência Política. USP. 2009.

GAMÓN, Efraín Enríquez. Em uma nueva simensión histórica: breve resumen de uma gestión patriótica. 2011?. Ed. ??. 
Assunção, Paraguai.

Itaipu, aguas que valen oro. 2007. Ed. ABC Collor.

GARBARINO, Alberto Costa: "A Crise no Paraguai:de onde vem e para onde vai". In: Revista Política Externa. Volume 21.2013

GOIRIS, Fabio A. J. Autoritarismo e Democracia no Paraguai Contemporâneo. 2000. Ed. UFPR.

ITAUSSU, Leonel. A geopolítica do Brasil e a Bacia do Prata. Ed. Da Universidade de Manaus. 1997

IPEA: Evolução recente do comércio exterior brasileiro com outros países do Mercosul. Disponível em: <http://www.ipea.gov.br/agencia/images/stories/PDFs/TDs/td_1466.pdf. Acesso em: 03.01.2014>.

ITAIPU. Presidente paraguaio inaugura obras na subestação da margem direita. Disponível em: https://www.itaipu.gov.br/sala-de-imprensa/noticia/presidenteparaguaio-inaugura-obras-na-subestacao-da-margem-direita. Acesso em:: 20.02.2014.

ITAIPU: Informações gerais sobre a usina. Disponível em http://itaipu.gov.br. Acesso em: 01.01.2014.

ITAIPU: Utilização de energia de Itaipu referente a cada país. Disponível em: <http://www.itaipu.gov.br/energia/geracao >. Acesso em: 03.01.2014

ITAIPU b: A história de Itaipu. Disponível em: http://www.itaipu.gov.br/nossa-historia. Acesso em:: 03.01.2014.

LAMBERT, Peter.a Dancing between superpowers: pragmatism and the limits of idealism in Paraguayan foreign policy. In: Gardini, G. L. and Lambert, P. W., eds. Latin American Foreign Policies: Between Ideology and Pragmatism. New York: Palgrave Macmillan.

b Undermining the new dawn: opposition to Lugo in Paraguay. In: Dominguez, F. Lievesley, G and Ludlam, S. Eds. Right-wing politics in the new Latin America: reaction and revolt. 2011. London, Zed Press.

Martin's Press. 1997

e NICKSON, Andrew: The transition to democracy in Paraguay.

PARAGUAI. Ministério das Relações Exteriores, 2008: Informe de los primeiros cien días de gestión. Disponível em: Ministerio de RREE Assunción.

PECEQUILO, Cristina Soreanu e HAGE, José Alexandre Altahyde. Dilemas Sul Americanos: O Brasil, o Paraguai e Itaipu. Revista Meridiano. 2007. Vol. 84.

PAULA, Orlando F. O Paraguai na agenda externa brasileira e a temática de ltaipu: 2003-2012. Dissertação de mestrado. Programa de Pós-Graduação em Relações Internacionais San Tiago Dantas (UNESP-UNCAMP-PUC-SP). 2013

PUTNAM, Robert D. Diplomacia e política doméstica: a lógica dos jogos de dois níveis. Revista de Sociologia e Política V.18 n. 36 pp. 147-174.Junho 2010.

RIVAROLA, Milda. Paraguai: Estado patrimonial e clientelismo. Revista Diplomacia Estratégia Política- DEP. No.6. 2007

ROETT, Riordan and SACKS, Richard Scott. Paraguay: The Personalist Legacy. Westview Press. 1991.

ROLON, José Aparecido: Paraguai: transição democrática e política externa. Tese de Doutorado. FFLCH, USP. 2010 
O Paraguai no Mercosul: Limites e Possibilidades. Dissertação de mestrado apresentada ao Programa de Pós-Graduação em Integração da América Latina (PROLAM) da USP. 2000

TOLEDO, Sara B. Mudança Política no Paraguai e as relações com o Brasil: a renegociação do Tratado de Itaipu. Dissertação de mestrado apresentado ao PPGRI San Tiago Dantas (UNESP-UNICAMP-PUC-SP). 2015.

YAHN FILHO, Armando Gallo. Conflito e cooperação na Bacia do Prata em relação aos cursos d'águas internacionais. (1966-1992). Dissertação de mestrado. PPGRI San Tiago Dantas. São Paulo, 2005.

Recebido em 04 de setembro de 2017. Aprovado em 05 de janeiro de 2018. 